\title{
STRATEGI KOMUNIKASI TIM GUGUS TUGAS COVID-19 DALAM PELAKSANAAN PEMBATASAN SOSIAL BERSKALA BESAR (PSBB)
}

\author{
Silmi Salimah ${ }^{1}$, Reni Nuraeni, Ph. D. ${ }^{2}$, Rizca Haqqu, M.Ikom. ${ }^{3}$ \\ ${ }^{1,2,3}$ Program Studi Ilmu Komunikasi, Fakultas Komunikasi dan Bisnis, Universitas \\ TelkomEmail: silmisalimah15@gmail.com
}

\begin{abstract}
Abstrak
Tujuan penelitian ini ialah untuk mengetahui penerapan strategi komunikasi yang dilaksanakan oleh Ketua Tim Gugus Covid-19 Kota Tasikmalaya dalam pelaksanaan Pembatasan Sosial Berskala Besar (PSBB). Metode penelitian yang digunakan ialah metode kualitatif dengan tekhnik pengumpulan data wawancara, observasi dan dokumentasi. Hasil penelitian menunjukkan bahwa pelaksanaan strategi komunikasi dilaksanakan oleh Tim Gugus Tugas Kota Tasikmalaya telah sesuai dengan indikator strategi komunikasi mulai dari strategi penetapan komunikator, strategi penetapan pesan, strategi penetapan media dan strategi penetapan khalayak telah dilakukan dengan baik. Strategi komunikasi yang di terapkan menghasilkan fakta bahwa penyebaran Covid-19 di Kota Tasikmalaya mengalami penurunan karena pelaksanaan kedisplinan yang dilakukan oleh aparat selaku Tim Satuan Gugus Tugas Covid-19 Kota Tasikmalaya dan komunikasi yang disampaikan kepada masyarakat dengan strategi yang tepat. Pelaksanaan strategi komunikasi yang telah di jalankan oleh tim Satuan Gugus Tugas, pelaksanaan pelaporan hasil presentasi kedispilinan Kota Tasikmalaya di laporkan langsung kepada Gubernur yang di bebankan kepada Kominfo dengan Pemerintah Daerah setempat.
\end{abstract}

Kata Kunci: Strategi Komunikasi, PSBB, Kota Tasikmalaya.

\begin{abstract}
The purpose of this study was to determine the implementation of the communication strategy carried out by the Head of the Tasikmalaya City Covid-19 Cluster Team in the implementation of Large-Scale Social Restrictions (PSBB). The research method used is a qualitative method with data collection techniques interview, observation and documentation. The results showed that the implementation of the communication strategy carried out by the Task Force Team of the City of Tasikmalaya was in accordance with the indicators of the communication strategy ranging from the communicator determination strategy, message determination strategy, media determination strategy and audience determination strategy. The communication strategy implemented resulted in the fact that the spread of Covid-19 in Tasikmalaya City had decreased due to the implementation of discipline carried out by the apparatus as the Tasikmalaya City Covid-19 Task Force Team and communication that was conveyed to the public with the right strategy. The implementation of the communication strategy that has been carried out by the Task Force Team, the implementation of the report on the results of the Tasikmalaya City discipline presentation is reported directly to the Governor who is charged to Kominfo with the local Government.
\end{abstract}

Keywords: Communication Strategy, PSBB, Tasikmalaya City. 


\section{A. PENDAHULUAN}

Hasil penerapan dari PSBB ini, kota di Jawa Barat yang berhasil menurunkan jumlah pasien secara signifikan adalah kota Tasikmalaya. Setelah 5 hari (yaitu tanggal 6-10 Mei) hari berjalannya PSBB di Kota Tasikmalaya, jumlah kasus warga yang positif Covid-19 tidak mengalami penambahan. Hal tersebut terlihat dari data Dinas Komunikasi dan Informatika Kota Tasikmalaya dalam Instagramnya @ kominfo_pemkot_tsm.

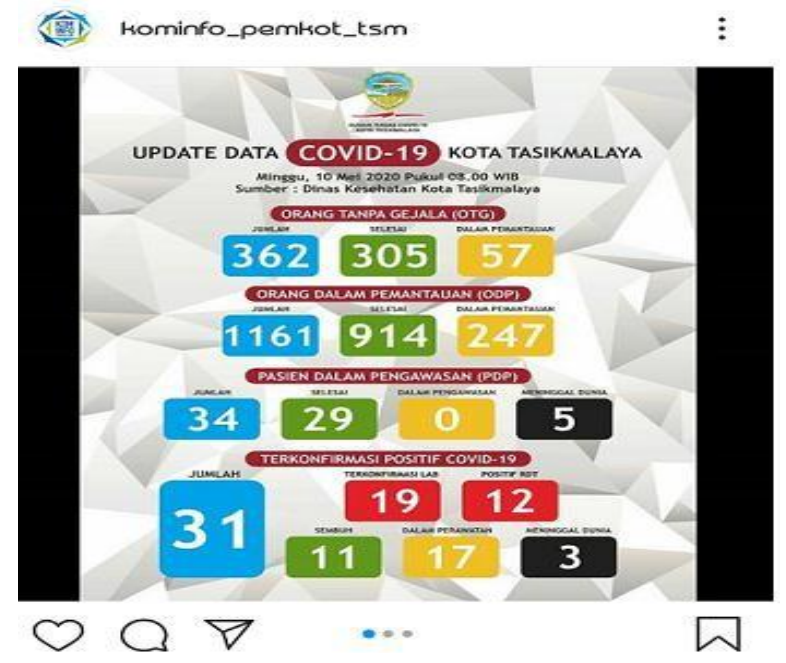

\section{Gambar 1 Update Data Covid-19 di Kota Tasikmalaya 10 Mei 2020}

Sumber: @kominfo_pemkot_tsm

Angka-angka tersebut di atas menunjukkan angka penyebaran Covid-19 tertahan selama berlangsungnya PSBB yang dimulai sejak Rabu 6-10 Mei 2020 Diskominfo Kota Tasikmalaya juga menyajikan data warga diketahui pada 10 Mei 2020 mencapai 34 orang dengan 29 selesai pengawasan, 0 dalam pengawasan, dan 5 meninggal dunia. Jumlah ODP sebanyak 1161 orang dengan 914 selesai pemantauan, 247 dalam pemantauan, kemudian data terakhir diketahui pada Juni 2020 Dinas Kesehatan Tasikmalaya mencatat bahwa pada akhir Juni 2020 hanya tertinggal 1 orang saja yang masih dirawat.

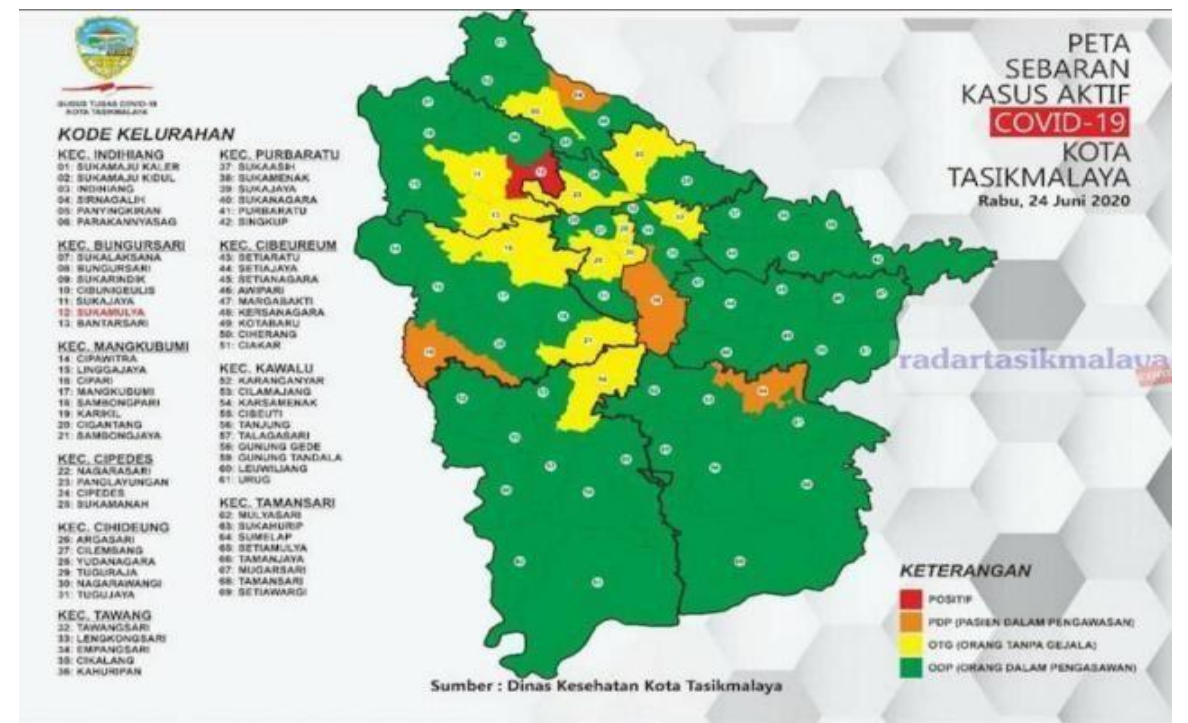

Gambar 2 Peta Sebaran Kasus Aktiv Covid-19 Kota Tasikmalaya

Sumber: Radar Tasikmalaya (Rizaldi, 2020) 
Berdasarkan gambar tersebut diatas diketahui bahwa Pasien Positif Covid-19 hanya terdapat pada kawasan wilayah Kecamatan Bungursari Kelurahan Sukamulya, hal tersebut tentu merupakan pencapaian terbaik Kota Tasikmalaya dalam memberlakukan strategi penanganan yang baik dalam mengatasi Covid-19 ini dengan hanya menyisakan satu orang pasien yang menderita positif Covid-19 (Rizaldi, 2020:1). Keberhasilan kota Tasikmalaya dalam menurunkan jumlah Pasien Covid-19 merupakan upaya luar biasa dengan melibatkan sejumlah pihak mengingat sebelumnya status kota Tasikmalaya ini adalah zona merah dan kini berhasil menurunkan hingga hanya tersisa 1 orang yang menderita Covid-19.

Penurunan jumlah pasien ini, adalah satu bentuk kerjasama yang baik oleh setiap lapisan pemerintahan kota Tasikmalaya terutama Tim Gugus Tugas Covid-19 Kota Tasikmalaya. Adapun elemen lengkap gugus tugas penanganan covid-19 ini Mulai dari Wali Kota dan Wakil Wali Kota, Sekretaris Daerah, Dandim 0612/Tasikmalaya, Kapolres Tasikmalaya Kota, Danlanud Wiriadinata Tasikmalaya, Kepala Bidang Keuangan dan Kepala Pelaksana BPBD hingga Kepala Kejaksaan Negeri Kota Tasikmalaya serta Tim gabungan Satpol PP, BPBD, Dishub serta TNI-Polri beserta seluruh anggota RT dan RW.

State of the art penelitian ini diantaranya ialah, penelitian yang dilakukan oleh Aulia (2019) dengan judul "Strategi Komunikasi Pemerintah Kota Tanggerang Via Aplikasi Tanggerang Live Dalam Menyampaikan Informasi Kepada Masyarakat Di Kota Tanggerang, Penelitian ini membahas mengenai Strategi Pemerintah Kota Tangerang dilaksanakan dengan tersediannya media saluran yang terdapat di aplikasi Tangerang Live dengan penggunaan konsep MRT (media richness theory) yaitu kemampuan media dalam menyampaikan beragam bentuk pesan, memberikan feedback secara langsung, personalisasi pesan dan memperlihatkan variasi bahasa. Selanjutnya penelitian yang dilakuka oleh (Wijaya, 2018) dengan judul penelitian "Strategi Komunikasi Pemerintah Kota Tangerang Via Aplikasi Tangerang Live Dalam Menyampaikan Informasi Kepada Masyarakat di Kota Tangerang”. Penelitian ini membahas mengenai Pemerintah Kabupaten Penajam Paser Utara telah memberikan informasi secara umum kepada masyarakat luas. Seperti pada pemilihan komunikator, pesan, media, khalayak dan feedback. Penelitian ini juga belum membentuk sebuah kualifikasi umur, gender, pekerjaan dalam membuat pesan. Serta dalam feedback, Pemerintah Kabupaten Penajam Paser Utara memeberikan feedback terhadap komunikan dengan cepat, baik dan sopan

Penelitian yang dilakukan oleh (Nurhikmahwati, 2015) dengan judul penelitian "Strategi Komunikasi Dinas Sosial Kota Makassar Dalam Upaya Pemberdayaan Masyarakat Di Tamangapa Kecamatan Manggala" Penelitian ini membahas mengenai pelaksanaan strategi komunikasi atau langkah-langkah komunikasi dilaksanakan secara tidak langsung melalui camat, RT, RW, dan Yayasan Pabbata Ummi dengan pengawasan, dari aparat pemerintah tersebut informasi pemberdayaan masyarakat disampaikan ke masyarakat dan juga dengan diadakannya kegiatan sosialisasi dan pelatihan terhadap masyarakat miskin. Serta, terdapat banyak faktor penghambat dalam kegiatan tersebut. Berdasarkan state of the art penelitian terdahulu yang telah dilakukan, Novelty atau unsur keterbaruan penelitian ini ialah membahas mengenai strategi komunikasi yang diterapkan oleh peran relawan medis berfokus kepada penanganan Covid-19 di fasilitas layanan kesehatan, sedangkan relawan non medis hadir ke tengah masyarakat untuk sosialisasi pencegahan penularan Covid-19 serta membantu pendistribusian bantuan mencegah tertularnya virus ini. Berdasarkan jumlah dan latar belakang diketahui bahwa Satuan Tim Gugus Tugas Covid-19 Kota Tasikmalaya berasal dari pekerjaan 
dan pendidikan yang beragam. Dalam pelaksanaannya diperlukan strategi yang khusus dan koordinasi yang tepat sehingga pencapaian keberhasilan penanganan dalam penurunan angka jumlah pasien covid-19 di Kota Tasikmalaya. Tujuan penelitian ini ialah untuk mengetahui bagaimana penerapan strategi komunikasi yang dilaksanakan oleh Ketua Tim Gugus Covid-19 kota Tasikmalaya dalam pelaksanaan Pembatasan Sosial Berskala Besar (PSBB) yang menjadi kebijakan terkini yang diterapkan kota Tasikmalaya sehingga dapat menurunkan jumlah pasien covid-19 hingga juni 2020 serta bagaimana rancangan kedepannya yang menjadi strategi komunikasi penanganan apabila nantinya jumlah pasien Covid-19 akan naik kembali.

\section{B. METODE}

Jenis penelitian yang digunakan yaitu penelitian deskriptif kualitatif. Penelitian ini menggunakan teknik pengumpulan data yaitu dengan wawancara, observasi, dan dokumentasi. Wawancara digunakan sebagai Teknik pengumpulan data apabila peneliti ingin melakukan studi pendahuluan untuk menemukan permasalahan yang harus diteiti, begitupun dengan observasi dan dokumentasi sebagai pendukung penelitian ini. Analisis data dilakukan dengan tiga tahapan yaitu reduksi data, penyajian data dan penarikkan kesimpulan.

\section{HASIL DAN PEMBAHASAN}

\section{Pembentukan Strategi Penetapan Komunikator}

Komunikator memiliki peran penting dalam menyampaikan pesan kepada khalayak. Untuk menjadi komunikator yang efektif, harus memiliki pengetahuan mengenai apa yang hendak disampaikan. Pengetahuan terbagi pada pengetahuan isi (content knowledge) yang dapat diperoleh dari berbagai literature. Lalu, pengetahuan prosedural (procedural knowledge) mengenai tata cara pelaksanaan dari konten yang disampaikan (Hasmawati, 2020:75).

Komunikator yang dibentuk oleh Satuan Gugus Tugas Kota Tasikmalaya dilakukan degan penetapan komunikator yang dipilih dari instansi-instansi lembaga pemerintahan yang memiliki potensi untuk memberikan arahan dan terjun ke masyarakat. Adapun keterangan yang diperoleh dari informan-informan diketahui bahwa instansi yang terlibat dan turut aktif dalam pelaksanaan PSBB di Kotas Tasikmalaya diantaranya ialah Dinas Kesehatan, Kepolisian Daerah setempat, TNI, Dinas Komunikasi Informasi, BPPD Kota Tasikmalaya dan lainnya.

Komunikator yang memiliki potensi ini memiliki pengalaman pada bidang masingmasing sesuai dengan keahlian yang dimiliki. Untuk pengalaman menangani covid-19 dan PSBB belum pernah dihadapi sebelumnya oleh para pihak mengingat covid-19 baru pertama kali melanda Indonesia, namun demikian komunikator yang berasal dari instansi Kepolisian dan TNI telah memiliki pelatihan sebelumnya mengenai penanganan wabah penyakit. Penunjukkan dan pemilihan komunikator dari lembaga instansi dikarenakan pihak pemerintahan dianggap sebagai pihak yang dianggap memiliki keahlian.

Berdasarkan penjelasan yang telah diuraikan, diketahui bahwa strategi pemilihan komunikator yang diterapkan oleh Pemerintah Kota Tasikmalaya telah tepat, sebab apabila dianalisis dengan pendapat yang dikemukakan oleh Suryanto, (2015:165), menjelaskan beberapa syarat yang perlu diperhatikan oleh seorang komunikator yaitu sebagai berikut: 
a. Memiliki kedekatan dengan khalayak, Komunikator yang dipilih dalam strategi pemilihan komunikator adalah para aparatur silpil negara dalam hal ini oknum pemerintahan dimana tugas inti dari para aparatur tersebut ialah melayani dan dekat dengan masyarakat.

b. Memiliki kesamaan dan daya tarik sosial serta fisik, Komunikator yang dipilih memiliki kesamaan dengan masyarakat dalam status mereka sebagai anggota masyarakat dan dengan keahlian serta kemampuan yang dimiliki dapat menarik perhatian masyarakat

c. Kesamaan yang meliputi gender, pendidikan, umur, agama, latar belakang sosial, ras, hobi dan kemampuan bahasa. Komunikator yang dipilih merupakan petugas dari pemerintahan Kota Tasikmalaya dan memiliki kemampuan bahasa yang baik dalam hal ini digunakan untuk bersosialisasi kepada masyarakat

d. Memiliki kredibilitas, Hal ini diketahui dari status yang dimiliki oleh Tim Satuan Gugus Tugas Kota Tasikmalaya yang merupakan orang pemerintahan sehingga kredibilitas dan otoritas yang dimiliki dapat dipercaya.

e. Pandai dalam cara penyampaian pesan, disertai dengan pengalaman yang dimiliki dalam memberikan pelayanan kepada masyarakat

f. Dikenal status, kekuasaan dan kewenangannya. Lewat seragam dan status pekerjaan yang dimiliki sehingga masyarakat mengetahui siapa yang sedang berbicara memberikan arahan dalam pelaksanaan PSBB.

\section{Pembentukan Strategi Penetapan Pesan}

Strategi penetapan pesan dilaksanakan oleh tim satuan gugus tugas dengan mengevaluasi isi pesan terlebih dahulu. Isi pesan yang dirumuskan dievaluasi secara bersama dan setiap instansi yang terlibat diperbolehkan memberikan saran dan masukkan dalam pesan yang dirumuskan tersebut. Pesan normatif dirumuskan dengan tidak menyalahi ketentuan peraturan perundang-undangan yang berlaku dalam hal ini termasuk isi Surat Edaran yang harus selalu diperbarui dan dievaluasi agar tidak bertentangan dengan setiap aturan perundangan yang berlaku di Kota Tasikmalaya.

Selanjutnya pembentukan strategi penetapan pesan edukatif dilaksanakan dengan menerapkan pesan yang berisikan pengetahuan dan pengarahan bagaimana pencegahan Covid19 dan aturan pelaksanaan PSBB yang dijalankan di Kota Tasikmalaya sejalan dengan apa yang dimaksud dengan Komunikasi edukatif itu sendiri yang merupakan proses menyampaikan informasi kepada orang atau pihak lain yang dilakukan secara terencana atas dasar kesadaran dengan maksud untuk menghasilkan sesuatu yang bermanfaat untuk dirinya, orang lain dan masyarakat. Setiap komunikasi selalu ada komunikan (penerima pesan) dan komunikator (orang yang menyampaikan pesan). Hubungan antara komunikan dan komunikator sangatlah dekat dalam arti selalu berinteraksi atau berhubungan secara intens untuk menyampaikan pesan. Indikator utama komunikasi dikatakan edukatif atau tidak terletak pada sejauh mana komunikasi tersebut memiliki maksud atau tujuan yang mulia yaitu sebagai proses humanisasi. Artinya komunikasi yang dibangun adalah dimaksudkan untuk memberdayakan manusia agar lebih menyadari hakekat dirinya sebagai manusia yang terikat dengan norma, aturan, etika atau sopan santun. Komunikasi yang baik dan benar dimaksudkan 
untuk meningkatkan kesadaran dan kualitas sikap dan perilakunya agar selalu sesuai dengan aturan dan norma (Muchith, 2015:181).

Isi pesan edukatif yang dirumuskan oleh para petugas gugus dalam pelaksanaan PSBB di Kota Tasikmlaya memenuhi indikator berupa pengarahan dan mendidik masyarakat untuk terikat dengan aturan yang diberlakukan di Kota Tasikmalaya mengenai pelaksanaan PSBB dan seperti apa kepatuhan yang harus dijalankan masyarakat selama masa PSBB ini berlangsung. Bentuk pesan berikutnya ialah pesan persuasive. Pesan ini dirumuskan oleh para satuan gugus tugas sebagai bentuk ajakan untuk melaksanakan PSBB dengan ketentuan yang diutamakan ialah mengajak untuk menerapkan $3 \mathrm{M}$ yaitu menjaga jarak, memakai masker dan mencuci tangan. Pesan persuasif juga berupa himbauan kepada warga bagaimana aturan yang diberlakukan apabila hendak mengadakan hajatan di tengah pandemi Covid-19. Pesan ini disampaikan dengan sosialisasi dan dilakukan oleh setiap anggota gugus tugas dengan porsi masing-masing yang dimiliki.

\section{Pembentukan Strategi Penetapan Media}

Media sebagai alat untuk menyampaikan pesan berperan penting, yang digunakan untuk menyebarluaskan serta menyampaikan pesan kepada komunikan yang menjadi sasarannya. Penggunaan media nirmassa digunakan dalam menjalin komunikasi antar anggota tim satuan gugus tugas, dengan memanfaat media sosial whatsapp yang digunakan dan dinilai efektif dalam menyampaikan pesan sehingga apabila ada hal yang hendak ditindaklanjuti segera diselesaikan secepat mungkin oleh setiap anggota dari masing-masing instansi.

Strategi penetapan media Komunikasi Bermedia melalui media massa diterapkan oleh para anggota gugus tugas yang ditujukan kepada seluruh lapisan masyarakat Kota Tasikmalaya dengan memanfaatkan media cetak, media elektronik dan media online dengan lebih mengedepankan website Mikotas hasil kerja dari Diskominfor Kota Tasikmalaya agar dapat memberikan pengarahan, pengetahuan dan informasi kepada masyarakat yang selalu diperbarui setiap harinya sehingga informasi yang disampaikan selalu dijaga keterbaruannya kemudian juga memanfaatkan media sosial misalnya facebook dan Instagram yang digunakan untuk kepentingan penyebaran informasi dan pesan kepada khalayak secara umum. Fenomena kehadiran media sosial sebagai dampak dari perkembangan teknologi informasi dan komunikasi memang luar biasa. Dengan berbagai layanan yang dapat digunakan, media sosial telah merubah cara berkomunikasi dalam masyarakat. Kehadiran media sosial bahkan membawa dampak dalam cara berkomunikasi di segala bidang.

\section{Pembentukan Strategi Penetapan Khalayak}

Khalayak dalam penelitian ini dibagi menjadi tiga kategori yaitu khalayak sekunder, primer dan tersier. Khalayak sekunder ditujukan kepada masyarakat Kota Tasikmalaya secara umum tanpa terkecuali hal ini dikarenakan agar PSBB berjalan dengan sebagaimana mestinya. Dalam ranah komunikasi massa, lebih banyak digunakan studi teori khalayak pasif. Khalayak dalam pandangan media merupakan target pesan yang cenderung menerima apa yang disampaikan media massa. Khalayak hampir tidak mempunyai pilihan untuk menentukan bentuk isi media. Atas dasar pemahaman tersebut, kekuatan media massa termasuk media online masih dipercaya oleh masyarakat. Khalayak dalam penelitian berikutnya ialah khalayak sekunder, khalayak sekunder dalam penelitian ini ditujukan kepada pejabat kelurahan, ketua 
RT pada setiap wilayah dan para tokoh masyarakat. Sebab para tokoh masyarakat dianggap sebagai pihak yang dapat diteladani untuk dijadikan contoh dalam pelaksanaan PSBB dan pencegahan covid-19 sesuai dengan surat edaran yang diberlakukan oleh Pemerintah Kota Tasikmalaya. Khalayak tersier dalam sasaran penyampaian pesan oleh Satuan Gugus Tugas covid-19 di Kota Tasikmalaya dalam hal ini ditujukan kepada para pelaku usaha sebagai pihak yang melaksanakan usaha bisnis di tengah pandemi covid-19 untuk mematuhi aturan pemberlakuan PSBB dan pencegahan covid-19.

Dengan pelaksanaan strategi komunikasi yang telah dijabarkan tersebut maka diketahui bahwaa Satuan Gugus Tugas Covid-19 secara sinergi dan bersama-sama melaksanakan penyampaian pesan kepada masyarakat untuk taat dan patuh dalam menerapkan aturan PSBB dan mencegah penyebaran covid-19 pelaksanaan komunikasi juga didukung dengan penindakkan langsung melalui tatap muka dan sosialisasi secara langsung dan penggunaan pos-pos yang tersebar di wilayah Kota Tasikmalaya untuk menindak masyarakat yang melanggar ketentuan PSBB sebagaimana mestinya.

\section{KESIMPULAN}

Berdasarkan hasil penelitian diketahui bahwa pelaksanaan strategi komunikasi dilaksanakan oleh Tim Gugus Tugas Kota Tasikmalaya telah sesuai indikator strategi komunikasi yang dikemukakan oleh (Cangara, 2017) yang memenuhi indikator sebagai berikut: Pembentukan Strategi Penetapan Komunikator, Indikator ini terpenuhi sebab berdasarkan hasil penelitian Pihak komunikator yang dipilih merupakan pihak yang menguasai bidang penanganan covid-19 yang berasal dari berbagai instansi masing-masing dimana hal ini sesuai dengan profesi komunikator dan pengalaman yang dimiliki.

Pembentukan Pembentukan Strategi Penetapan Pesan, Indikator ini diterapkan oleh tim Satuan Gugus Tugas, sebab berdasarkan fakta yang ditemukan di lapangan bahwa penentuan isi pesan terbagi menjadi pesan normatif, pesan edukatif dan pesan persuasive. Pesan disampaikan melalui berbagai media phamplet, media sosial dengan baju dan rompi khusus yang digunakan maupun dengan sosialisasi langsung ke masyarakat. Pembentukan Strategi Penetapan Media, Strategi penetapan media yang digunakan oleh satuan gugus tugas ialah penggunaan whatsapp sebagai media yang digunakan antar anggota atau yang dikategorikan sebagai media nirmassa. Kemudian media massa yang digunakan ialah media online khususnya Mikotas yang dibentuk oleh Diskominfo Tasikmalaya dalam penanganan Covid19.

Pembentukan Strategi Penetapan Khalayak, Strategi penetapan khalayak berdasarkan hasil penelitian Primary target audience yang ditujukan kepada seluruh lapisan masyarakat Kota Tasikmlaya. Kemudian Secondary target audience ialah para pelaku UMKM dan pengusaha, selanjutnya para stakeholder yang ditujukan kepada tokoh masyarakat, jajaran RT hingga lurah. Strategi komunikasi yang diterapkan menghasilkan fakta yang ditemukan di masyarakat bahwa penyebaran covid-19 di Kota Tasikmalaya mengalami penurunan karena pelaksanaan kedisplinan yang dilakukan oleh aparat selaku Tim Satuan Gugus Tugas Kota Tasikmalaya dan komunikasi yang disampaikan kepada masyarakat dengan strategi yang tepat. Mengenai akibat dari pelaksanaan strategi komunikasi yang telah dijalankan oleh tim Satuan Gugus Tugas, pelaksanaan pelaporan hasil presentasi kedispilinan kota Tasikmalaya 
dilaporkan langsung kepada Gubernur yang dibebankan kepada Kominfo dengan Pemerintah

Daerah setempat.

\section{DAFTAR PUSTAKA}

Aulia, R. (2019). Strategi Komunikasi Pemerintah Kota Tangerang Via Aplikasi Tangerang Live Dalam Menyampaikan Informasi Kepada Masyarakat Di Kota Tangerang. Universitas Sultan Ageng Tirtayasa.

Effendy, O. U. (2002). Hubungan Masyarakat Suatu Studi. Komunikologis. Bandung: Remaja Rosdakarya.

Effendy, O. U. (2011). Ilmu Komunikasi: Teori dan Prakteknya. Bandung: Remaja Rosdakarya.

Hasmawati, F. (2020). Dalam Komunikasi Antar Pribadi. 4(2), 69-95.

Jaenal, A. (2013). Metode Penelitian Sosial. Jakarta: UIN Jakarta Press.

Kalianda, D. (2018). Strategi Komunikasi Dinas Lingkungan Hidup (DLH) dalam Mengimplementasikan Program Green City di Kota Teluk Kuantan Kabupaten $\begin{array}{lllll}\text { Kuantan Singingi. } & \text { JOM } & \text { FISIP, } & \text { 5(1), }\end{array}$ https://doi.org/10.1017/CBO9781107415324.004

Mikotas. (2021). Media Informasi \& Koordinasi Penanggulangan Korona Kota Tasikmalaya. Retrieved from Mikotas website: http://mikotas.tasikmalayakota.go.id/

Muchith, M. S. (2015). Membangun Komunikasi Edukatif. AT-TABSYIR: Jurnal Komunikasi Penyiaran Islam, 3(1), 165-184. Retrieved from journal.stainkudus.ac.id/index.php/komunikasi/article/download/1657/1493\%0A\%0A

Nurhikmahwati, A. (2015). 'Strategi Komunikasi Dinas Sosial Kota Makassar Dalam Upaya Pemberdayaan Masyarakat di Tamangapa Kecamatan Manggala. UIN Alauddin Makassar.

Rizaldi, R. (2020). Kota Tasik Tersisa 1 Pasien Positif Covid-19. Retrieved from Radar Tasik Malaya. Diakses dari https://www.radartasikmalaya.com/kota-tasik-tersisa-1-pasienpositif-covid-19/

Suryanto. (2015). Pengantar Ilmu Komunikasi (1). Bandung: Pustaka Setia.

Tasikmalaya, K. (2021). Instagram Kominfo Tasikmalaya. Retrieved from Instagram website: https://www.instagram.com/kominfo_pemkot_tsm/?hl=id

Wijaya, B. Y. (2018). Analisis Strategi Komunikasi Dalam E-Government Di Pemerintah Kabupaten Penajam Paser Utara. Univesitas Islam Indonesia. 